\title{
Pendugaan Bobot Badan Ternak Kambing Betina Berdasarkan Ukuran Linear Tubuh di Desa Boronubaen Kecamatan Biboki Utara Kabupaten Timor Tengah Utara
}

\author{
Maria Yoda Haki \\ Fakultas Pertanian, Universitas Timor, Kefamenanu, TTU - NTT, Indonesia, email: mariayodahaki@gmail.com
}

\section{Article Info}

Article history:

Received 20 Mei 2019

Received in revised form 22 Agustus 2019

Accepted 5 Oktober 2019

DOI:

https://doi.org/10.32938/ja.v4i4.686

\section{Keywords:}

Bobot Badan Kambing Betina

Panjang Badan

Lingkar Dada

Tinggi Pundak

\begin{abstract}
Abstrak
Penelitian ini bertujuan untuk menduga bobot badan ternak kambing betina yang dipelihara secara tradisional oleh petani peternak di Desa Boronubaen Kecamatan Biboki Utara Kabupaten Timor Tengah Utara. Pengambilan sampel penelitian dan ternak dilakukan dengan proposive sampling. Ternak yang menjadi objek penelitian adalah 23 ekor kambing betina milik peternak dengan umur yang berbeda-beda yakni 1 dan 2 tahun dilihat berdasarkan gigi seri tetap. Metode yang digunakan dalam penelitian ini adalah metode eksperimen dengan melakukan pengukuran langsung terhadap linear tubuh ternak kambing betina dan bobot badan. Variabel yang diukur dalam penelitian ini meliputi pendugaan bobot badan, panjang badan, lingkar dada, tinggi pundak. Data yang diperoleh dianalisis dengan analisis regresi linear sederhana sesuai petunjuk (Akdon, 2013). Dengan model matematikanya adalah: $\mathrm{Y}=\mathrm{a}+\mathrm{bX}$. Dimana, $\mathrm{Y}=\mathrm{Nila}$ yang diramalkan/ subjek variabel terikat yang diproyeksikan; $A=$ Nilai Konstansta harga; $b=$ Koefesien regresi/Nilai arah sebagai penentu ramalan/prediksi yang menunjukkan nilai peningkatan (+) atau nilai penurunan (-) variabel Y ; X = Variabel bebas. Disimpulkan bahwa panjang badan pada umur ternak satu tahun dan lingkar dada memiliki pendugaan yang kuat dan dengan bobot badan dengan nilai masing-masing adalah 0,895 dan umur dua tahun 0,538,dan lingkar dada umur satu tahun 0,674 dan umur dua tahun lingkar dada 0,535. 2.Tinggi pundak memiliki keereatan hubungan yang kuat dan singnifikasi dengan bobot badan ternak kambing.
\end{abstract}

\section{Pendahuluan}

Kambing merupakan ternak ruminansia kecil yang sangat digemari oleh sebagian besar masyarakat. Pemeliharaan ternak kambing yang mudah dan relatif sederhana serta peluang pengembangan yang tinggi sehingga menarik minat peternak. Hal tersebut merupakan peluang yang harusdidukung oleh semua pihak dalam upaya pengembanganternak kambing khususnya pengembangan peternakan pada umunya

Pengembangan kambing mempunyai prospek yang baik karena di samping itu memenuhi kebutuhan daging di dalam negeri, juga memiliki peluang sebagai komoditas ekspor. Ternak kambing juga merupakan bagian yang integral dalam usahatani diNusa Tenggara Timur ( NTT ). Sistem usaha ternak kambing masih sangat tradisional dan skala kecil yang masih bersifat sambilan dengan ternak dilepas mencari makan sendiri pada siang hari oleh peternak di NTT.

Data mengenai pengembangan populasi ternak kambing di NTT masih sangat terbatas terutama menyangkut sistem pemeliharaan. Menyadari pentingnya data tersebut, maka pengembangan ternak kambing di NTT perlu memperhatikan beberapa hal dalam sistem ukuran linear tubuh ternak kambing betina antara lain panjang badan, lingkar dada, tinggi pundak yang meliput peranan dan potensi pemeliharaan dan prospeknya sebagai masukan dalam penyusunan program kebijakan pengembangan usaha ternak kambing di Nusa Tenggara Timur

Penentuan bobot badan dinilai semakin penting karena sangat diperlukan dalam manajemen peternakan kambing kacang. Bobot badan ternak dapat digunakan untuk menentukan kebutuhan pakan,produksi daging, penentuan bibit harga jual beli. Secara umum ada dua teknik penentuan bobot badan seekor ternak yaitu penimbangan dan pendugaan. Kedua teknik tersebut memiliki keuntungan dan keterbatasan masing-masing. Penimbangan adalah cara terbaik dalam menentukan bobot hidup ternak namun kurang efisien. Sehingga peternak belum mengetahui ketersediaan dan sulit dijangkau dalam teknologi sederhana untuk membantu masyarakat kecil di desa pedalaman.

Metode pendugaan umumnya dilakukan dengan menggunakan ukuranukuran linear tubuh ternak seperti lingkar dada, panjang badan, tinggi pundak, manfaat dari menduga untuk mengetahui ternak kambing kacang yang normal atau sehat (Meivilia, 2011) .Tujuan dari penelitian ini adalah untuk mengetahui bobot badan ternak berdasarkan ukuran linear tubuh panjang badan (PB) lingkar dada (LD), dan tinggi pundak (TP), pada kambing betina berdasarkan ukuran linear tubuh di Desa Boronubaen Kecamatan Biboki Utara Kabupaten Timor Tengah Utara.

\section{Metode}

\subsection{Tempat dan Waktu Penelitian}

Penelitian ini dilaksanakan di Desa Boronubaen Kecamatan Biboki Utara Kabupaten Timor Tengah Utara pada bulan September sampai Desember 2018.

\subsection{Materi Penelitian}

Materi yang digunakan dalam penelitian ini adalah 23 ekor Ternak Kambing betina umur 1-2 tahun dan umur dilihat dari jumlah gigi seri tetap. Peralatan yang digunakan meliputi timbangan gantung dengan kapasitas 100 $\mathrm{kg}$, pita ukur merk universal, tongkat ukur, kamera dan alat tulis.

\subsection{Teknik Penentuan Sampel}

Penentuan sampel dilakukan secara purposive sampling (secara sengaja) survey pendahuluaan untuk mengetahui status kepemilikan ternak dan lama beternak. Ternak yang menjadi objek penelitian sebanyak 23 ekor ternak kambing betina dari peternak tradisional.

\subsection{Variabel Penelitian}

Variabel yang diamati dalam penelitian adalah pendugaan bobot badan dari panjang badan, pendugaan bobot badan dari Lingkar dada dan pendugaan bobot badan dari tinggi Pundak.

\subsection{Prosedur Penelitian}

Survei pendahuluan untuk mengetahui status kepemilikan ternak dan lama beternak. Persiapan ternak, alat pengukur dan timbangan. Mengukur dan mencatat bobot badan, panjang badan, tinggi pundak, lingkar dada. Prosedur pengukur Panjang badan diukur dari jarak garis lurus dari tepi tulang processusspinosus sampai osischium, pengukuran dilakukan dengan tongkat ukur dalam satuan $\mathrm{cm}$. Prosedur pengukur Lingkar dada diukur melingkari rongga dada (body of sternum) di belakang sendi bahu, pengukuran dilakukan dengan pita ukur dalam satuan $\mathrm{cm}$. Prosedur pengukuran Tinggi pundak diukur dari jarak tertinggi pundak sampai permukaan tanah, pengukuran dilakukan dengan menggunakan tongkat ukur dalam satuan $\mathrm{cm}$ serta wawancara dengan peternak untuk mengetahui sistem pemeliharaan ternak kambing kacang di lokasi penelitian.

\subsection{Analisis Data}

Data yang diperoleh dianalisis dengan analisis regresi linear sederhana sesuai petunjuk (Akdon dan Riduwan, 2013). Dengan model matematikanya adalah: $\mathrm{Y}=\mathrm{a}+\mathrm{bX}$. Dimana, $\mathrm{Y}=$ Nilai yang diramalkan/ subjek variabel terikat yang diproyeksikan; $A=$ Nilai Konstansta harga; $b=$ Koefesien regresi/Nilai arah sebagai penentu ramalan/prediksi yang menunjukkan nilai peningkatan $(+)$ atau nilai penurunan (-) variabel $\mathrm{Y} ; \mathrm{X}=$ Variabel bebas.

\section{Hasil dan Pembahasan}

3.1 Rata-rata Panjang Badan, Lingkar Dada, Tinggi Pundak dan Bobot Badan

Ukuran-ukuran linear tubuh ternak kambing pada penelitian ini dikelompokkan berdasarkan sampel yang dibutuhkan yaitu ternak kambing dengan kondisi umur 1 sampai 2 tahun. Rata-rata ukuran linear tubuh ternak kambing di Desa Boronubaen Kecamatan Biboki Utara Kabupaten Timor Tenggah Utara dapat dilihat pada Tabel 1.

Tabel 1. Ukuran Linear Tubuh Kambing Kacang Pada Umur1 tahun dan 2 tahun.

\begin{tabular}{|c|c|c|c|c|c|}
\hline \multirow{2}{*}{ Variabel } & \multicolumn{5}{|c|}{ Umur 1 tahun } \\
\hline & Rata-rata & Min & Max & SD & KV \\
\hline Bobot badan (Kg) & 12,14 & 7,5 & 20,5 & 4,16 & 34,26 \\
\hline Panjang badan $(\mathrm{cm})$ & 46,1 & 34 & 59 & 8,58 & 18,62 \\
\hline Lingkar dada $(\mathrm{cm})$ & 47 & 35 & 64 & 9,46 & 20,14 \\
\hline Tinggi pundak $(\mathrm{cm})$ & 44,44 & 33 & 62 & 8,88 & 19,98 \\
\hline \multirow{2}{*}{ Variabel } & \multicolumn{5}{|c|}{ Umur 2 tahun } \\
\hline & Rata-rata & Min & Max & SD & KV \\
\hline Bobot badan (Kg) & 20,07 & 15,6 & 25,7 & 2,63 & 13,1 \\
\hline Panjang badan $(\mathrm{cm})$ & 55,02 & 44 & 64,2 & 5.05 & 9,17 \\
\hline Lingkar dada $(\mathrm{cm})$ & 61,62 & 56 & 68 & 4,49 & 7,28 \\
\hline Tinggi pundak $(\mathrm{cm})$ & 54,38 & 49,1 & 61 & 3,78 & 6,96 \\
\hline
\end{tabular}

Sumber: Data primer diolah (2018)

Berdasarkan data pada Tabel 1, ukuran linear tubuh ternak kambing menunjukkan bahwa bobot badan umur 1 tahun adalah minimum 7,5 kg dan maksimum $20,5 \mathrm{~kg}$ dengan rata-rata $12,14 \mathrm{~kg}$, sedangkan pada umur 2 tahun bobot badan minimum $15,6 \mathrm{~kg}$ dan maksimum $25,7 \mathrm{~kg}$ dengan rata-rata 20,07 $\mathrm{kg}$. Hal ini berkaitan dengan tumbuh kembang ternak kambing, yang mengalami pertumbuhan secara cepat dimulai dari lahir sampai dewasa kelamin dan tumbuh secara lambat sampai dewasa. Bobot badan merupakan salah satu 
tingkat produktivitas ternak, yang dapat digunakan sebagai pedoman dasar pemilihan bibit maupun bakalan (Pratama et al., 2016).

Hasil penelitian untuk rata-rata ukuran linear tubuh panjang badan ternak kambing pada umur 1 tahun adalah minimum $34 \mathrm{~cm}$ dan maksimum $59 \mathrm{~cm}$ dengan rara-rata $46,1 \mathrm{~cm}$; dan pada umur 2 tahun minimum $44 \mathrm{~cm}$ dan maksimum 64,2 $\mathrm{cm}$ dengan hasil rara-rata 55,02 cm.Lingkar dada pada umur 1 tahun adalah minimum $35 \mathrm{~cm}$ dan maksimal $64 \mathrm{~cm}$ dengan rata-rata $47 \mathrm{~cm}$; dan pada umur 2 tahun minimum $56 \mathrm{~cm}$ dan maksimal $68 \mathrm{~cm}$ dengan rata-rata $61,62 \mathrm{~cm}$. Untuk tinggi pundak ternak pada umur 1 tahun adalah minimum 33 $\mathrm{cm}$ dan maksimum $62 \mathrm{~cm}$ dengan rata-rata $44,44 \mathrm{~cm}$; dan pada umur 2 tahun minimum $49,1 \mathrm{~cm}$ dan maksimum $61 \mathrm{~cm}$ dengan rata-rata $54,38 \mathrm{~cm}$.

Hal ini menunjukkan bahwa rata-rata ukuran linear tubuh ternak kambing kacang yang dipelihara di Desa Boronubaen sedikit lebih rendah bila dibandingkan dengan hasil penelitian Komariah et al., (2015) yang dilakukan di Mitra Tani Farm Desa Tegal Waru Kabupaten Bogor, Jawa Barat yakni sebesar $63,9 \pm 6,2 \mathrm{~cm}$ dan $53,2 \pm 6,2 \mathrm{~cm}$ masing-masing untuk panjang badan dan lingkar dada. Demikian pula bobot tubuh yang juga lebih tinggi yaitu $25,8 \pm 4,5 \mathrm{~kg}$. Perbedaan lingkungan dan pakan diduga menjadi penyebab perbedaan tersebut. Menurut Parakassi (1999) pertumbuhan hewan muda sebagian besar disebabkan oleh pertumbuhan otot, tulang belulangdan organ-organ vital. Proses pertumbuhan pada semua jenis hewan terkadang berlangsung cepat, lambatdan bahkan terhenti jauh sebelum hewan tersebut mencapai dalam ukuran besartubuh karena dapat dipengaruhi oleh faktor genetis ataupun lingkungan (Bambang, 2005).

\subsection{Hubungan Bobot Badan Berdasarkan Panjang Badan}

Hubungan berbagai ukuran linear tubuh (panjang badan) berkorelasi sangat nyata $(\mathrm{P}<0,01)$ dengan bobot badan seperti yang terlihat pada Tabel 2 .

Tabel 2. Hasil Analisis Regresi sederhana Pendugaan bobot badan kambing betina berdasarkan Panjang Badan

\begin{tabular}{|c|c|c|c|c|}
\hline $\begin{array}{l}\text { Umur } \\
\text { ternak }\end{array}$ & $\mathrm{R}$ & $\begin{array}{c}\mathrm{R} \\
\text { Square }\end{array}$ & $\begin{array}{l}\text { Adjusted R } \\
\text { Square }\end{array}$ & Std. Error of the Estimate \\
\hline 1 &, $895^{\mathrm{a}}$ & 801 &, 776 & 1,97008 \\
\hline \multicolumn{5}{|c|}{$\begin{array}{l}\text { a. Predictors: (Constant), Panjang badan } \\
\text { b. Dependent Variable: Bobot badan }\end{array}$} \\
\hline $\begin{array}{l}\text { Umur } \\
\text { ternak }\end{array}$ & $\mathrm{R}$ & $\begin{array}{c}\mathrm{R} \\
\text { Square }\end{array}$ & $\begin{array}{l}\text { Adjusted R } \\
\text { Square }\end{array}$ & Std. Error of the Estimate \\
\hline 2 &, $538^{\mathrm{a}}$ & ,289 &, 224 & 2,31480 \\
\hline
\end{tabular}

Hasil analisis regresi linear tubuh berdasarkan data pada Tabel 2 menunjukkan bahwa nilai koefisien korelasi (r) sebesar 0,895. Hal ini menunjukkan ada hubungan yang sangat kuat antara linear tubuh panjang badan (PB) dengan bobot badan (BB). Koefisien determinasi $\left(\mathrm{R}^{2}\right)$ sebesar 0,801 memberi pengertian bahwa besarnya bobot badan ternak kambing betina yang dapat diterangkan oleh panjang badan adalah sebesar $80,1 \%$. Artinya $80,1 \%$ bobot badan ternak kambing dipengaruhi oleh panjang badan. Sebaliknya dari bobot badan dipengaruhi oleh faktor lain yang tidak diteliti, misalnya faktor manajemen pemeliharaan baik karena ternak pada siang hari dilepaskan mencari makanan sendiri sehingga bobot badan ternak kambing jauh lebih baik serta kebutuhan ternak dan faktor genetik. Ternak umur dua tahun korelasi sebesar 0,538, koefisien determinasi ( $\mathrm{r} 2$ ) sebesar 0,289 memberi pengertian bahwa $28,9 \%$ makin menurunnya pengaruh panjang badan terhadap bobot badan. Hal ini karena ternak sudah mencapai umur kedewasaan selain itu dipengaruhi oleh pola pemeliharaan. Ni'am et al. (2012) menyatakan bahwa pola pemeliharaan yang baik memegang peranan penting untuk menentukan kebutuhan nutrisi, jumlah pemberian pakan, jumlah dosis obat, bobot badan juga dapat digunakan untuk menentukan nilai jual ternak tersebut.

Tabel 3. Hasil analisis variable untuk mengetahui pengaruh linear panjang badan terhadap bobot badan.

\begin{tabular}{|c|c|c|c|c|c|c|}
\hline \multicolumn{2}{|c|}{ Umur ternak } & $\begin{array}{l}\text { Sum of } \\
\text { Squares }\end{array}$ & Df & $\begin{array}{c}\text { Mean } \\
\text { Square }\end{array}$ & F & Sig. \\
\hline \multirow{3}{*}{1} & Regression & 124,654 & 1 & 124,654 & 32,117 &, $000^{\mathrm{b}}$ \\
\hline & Residual & 31,050 & 8 & 3,881 & & \\
\hline & Total & 155,704 & 9 & & & \\
\hline \multicolumn{7}{|c|}{$\begin{array}{l}\text { a. Dependent Variable: bobot badan } \\
\text { b. Predictors: (Constant), Panjang badan }\end{array}$} \\
\hline \multicolumn{2}{|c|}{ Umur ternak } & $\begin{array}{l}\text { Sum of } \\
\text { Squares }\end{array}$ & $\mathrm{Df}$ & $\begin{array}{c}\text { Mean } \\
\text { Square }\end{array}$ & $\mathrm{F}$ & Sig. \\
\hline \multirow{3}{*}{2} & Regression & 23,966 & 1 & 23,966 & 4,473 &, $058^{\mathrm{b}}$ \\
\hline & Residual & 58,941 & 11 & 5,358 & & \\
\hline & Total & 82,908 & 12 & & & \\
\hline
\end{tabular}

Nilai F hitung 32,117 memberikan pengertian bahwa dengan persamaan $\mathrm{Y}=\mathrm{a}+\mathrm{bX}$ dimana komponen linear tubuh panjang badan berpengaruh sangat nyata terhadap bobot badan. Sebaliknya ternak umur 2 tahun, nilai $F$ hitung 4,473 dengan persamaan $y=a+b x$ dimana komponen linear tubuh panjang badan berpengaruh sangat nyata terhadap bobot badan. Untuk mengetahui persamaan garis regresi dan nilai $t$ dari variable panjang badan dapat dilihat pada Tabel 4 .

\begin{tabular}{|c|c|c|c|c|c|}
\hline \multirow{2}{*}{$\begin{array}{l}\text { Umur } \\
\text { ternak }\end{array}$} & \multicolumn{2}{|c|}{$\begin{array}{c}\text { Unstandardized } \\
\text { Coefficients }\end{array}$} & \multirow{2}{*}{$\begin{array}{c}\begin{array}{c}\text { Standardized } \\
\text { Coefficients }\end{array} \\
\text { Beta }\end{array}$} & \multirow[t]{2}{*}{$\mathrm{T}$} & \multirow[t]{2}{*}{ Sig. } \\
\hline & $\mathrm{B}$ & Std. Error & & & \\
\hline (Constant) & $-7,851$ & 3,582 & & $-2,192$ & 0,060 \\
\hline $\begin{array}{l}1 \text { Panjang } \\
\text { badan }\end{array}$ & ,434 & ,077 & 895 & 5,667 &, 000 \\
\hline \multicolumn{6}{|c|}{ a. Dependent Variable: Bobot badan } \\
\hline Umur ternak & \multicolumn{2}{|c|}{$\begin{array}{c}\text { Unstandardized } \\
\text { Coefficients }\end{array}$} & $\begin{array}{c}\text { Standardized } \\
\text { Coefficients } \\
\text { Beta }\end{array}$ & $\mathrm{T}$ & Sig. \\
\hline (Constant) & 4,664 & 7,313 & & ,638 & ,537 \\
\hline $\begin{array}{l}2 \text { panjang } \\
\text { badan }\end{array}$ & ,280 & ,132 &, 538 & 2,115 &, 058 \\
\hline
\end{tabular}

Berdasarkan data pada Tabel 4 diperoleh nilai t panjang badan umur 1 tahun dan 2 tahun adalah sangat signifikan $(\mathrm{P}<0.00)$. Sebaliknya umur ternak 1 tahun adalah $(\mathrm{P}<0,58)$. Persamaan regresi umur ternak 1 tahun menjadi $\mathrm{Y}=$ $7,851+0,434$, yang dapat diartikan sebagai berikut: konstanta sebesar $-7,851$ artinya bila bobot badan (x) nilainya adalah 0 , maka panjang badan nilainya sebesar negatif $-7,851$, sebaliknya koefisien regresi variabel $(x)=0,434$ artinya jika bobot badan mengalami kenaikan $0,1 \mathrm{~kg}$ maka panjang badan mengalami kenaikan $0,434 \mathrm{~cm}$. Sebaliknya panjang badan umur ternak 2 tahun memiliki persamaan $\mathrm{y}=4,664+0.280$, yang dapat diartikan sebagai berikut: konstantan sebesar 4,664 artinya bila bobot badan (x) nilainya adalah 0 , maka panjang badan nilainya sebesar negatif 4,664, sebaliknya koefisien regresi variabel $(\mathrm{x})=$ 0,280 artinya jika bobot badan mengalami kenaikan $0,1 \mathrm{~kg}$ maka panjang badan mengalami kenaikan $0,280 \mathrm{~cm}$.

\subsection{Hubungan Bobot Badan Berdasarkan Lingkar Dada}

Hubungan ukuran linear tubuh (lingkar dada) sangat nyata $(\mathrm{P}<0,01)$ dengan bobot badan (Tabel 5 ).

Tabel 5. Hasil Analisis Regresi sederhana Pendugaan bobot badan kambing betina berdasarkan Lingkar dada.

\begin{tabular}{ccccc}
\hline $\begin{array}{c}\text { Umur } \\
\text { ternak }\end{array}$ & $\mathrm{R}$ & $\mathrm{R}$ Square & $\begin{array}{c}\text { Adjusted } \mathrm{R} \\
\text { Square }\end{array}$ & $\begin{array}{c}\text { Std. Error of the } \\
\text { Estimate }\end{array}$ \\
\hline 1 &, $674^{\mathrm{a}}$ &, 454 &, 386 & 3,25870 \\
\hline
\end{tabular}

a. Predictors: (Constant), Lingkar dada

b. Dependent Variable: Bobot badan

\begin{tabular}{ccccc}
\hline $\begin{array}{c}\text { Umur } \\
\text { ternak }\end{array}$ & $\mathrm{R}$ & $\mathrm{R}$ Square & $\begin{array}{c}\text { Adjusted R } \\
\text { Square }\end{array}$ & $\begin{array}{c}\text { Std. Error of the } \\
\text { Estimate }\end{array}$ \\
\hline 2 &, $535^{\text {a }}$ &, 286 &, 221 & 2,31920 \\
\hline
\end{tabular}

\section{a. Predictors: (Constant), Lingkar dada}

Hasil analisis regresi linear sederhana berdasarkan data pada Tabel 5 menunjukan bahwa nilai koefisien korelasi (r) sebesar 0,674. Hal ini menunjukkan ada hubungan yang sangat kuat antara linear tubuh lingkar dada (LD) dengan bobot badan (BB). Koefisien determinasi $\left(\mathrm{R}^{2}\right)$ sebesar 0,454 memberi pengertian bahwa besarnya bobot badan ternak kambing betina dapat diterangkan oleh lingkar dada adalah sebesar $45,4 \%$. Artinya lingkar dada pada umur satu tahun memiliki pengaruh $45.4 \%$ terhadap bobot badan yang memiliki pertumbuhan baik, oleh karena itu ternak memiliki genetik yang unggul, ternak kambing dilepas untuk mencari makanan sendiri. Sebaliknya umur ternak 2 tahun adalah nilai koefisien korelasi (r) sebesar 0,535

Koefisien determinasi $\left(\mathrm{R}^{2}\right)$ sebesar 0,286 memberi pengertian bahwa besarnya bobot badan ternak kambing betina dapat diterangkan oleh lingkar dada adalah sebesar $28.6 \%$ Artinya pengaruh lingkar dada terhadap bobot badan sebesar $28,6 \%$. Sebaliknya dipengaruhi oleh faktor lain yang tidak diteliti, misalnya faktor lingkungan, pakan yang baik tidak memiliki genetik yang unggul maka pertumbuhan tidak maksimal dan masih bersifat tradisional. Hal ini sesuai dengan Ni'am et al. (2012) bahwa pola pemeliharaan yang baik memegang peranan penting dalam menentukan bobot hidup seekor ternak. Hasil analisis variansi untuk mengetahui pengaruh linear panjang badan terhadap bobot badan seperti tersaji padaTabel 6 .

Nilai F hitung 6,663 memberikan pengertian bahwa dengan persamaan $\mathrm{Y}=\mathrm{a}+\mathrm{bX}$ dimana komponen linear tubuh lingkar dada berpengaruh sangat nyata terhadap bobot badan. Sebaliknya nilai $\mathrm{F}$ hitung pada ternak umur 2 tahun adalah 4,473 dengan persamaan $\mathrm{Y}=\mathrm{a}+\mathrm{bX}$ dimana komponen lingkar dada sangat nyata terhadap bobot badan. Untuk mengetahui persamaan garis regresi dan nilai t dari variable lingkar dada dapat dilihat pada Tabel 7.

\section{Tabel 6. Koefisien determinasi dan uji F}

\begin{tabular}{|c|c|c|c|c|c|c|}
\hline \multicolumn{2}{|c|}{ Umur ternak } & $\begin{array}{l}\text { Sum of } \\
\text { Squares }\end{array}$ & Df & $\begin{array}{l}\text { Mean } \\
\text { Square }\end{array}$ & $\mathrm{F}$ & Sig. \\
\hline \multirow{3}{*}{1} & Regression & 70,751 & 1 & 70,751 & 6,663 &, $033^{\mathrm{b}}$ \\
\hline & Residual & 84,953 & 8 & 10,619 & & \\
\hline & Total & 155,704 & 9 & & & \\
\hline
\end{tabular}

a. Dependent Variable: Bobot badan

b. Predictors: (Constant) Lingkar dada 


\begin{tabular}{|c|c|c|c|c|c|c|}
\hline & Jmur ternak & $\begin{array}{l}\text { Sum of } \\
\text { Squares }\end{array}$ & Df & $\begin{array}{c}\text { Mean } \\
\text { Square }\end{array}$ & $\mathrm{F}$ & Sig. \\
\hline \multirow{3}{*}{2} & Regression & 23,966 & 1 & 23,966 & 4,473 &, $058^{\mathrm{b}}$ \\
\hline & Residual & 58,941 & 11 & 5,358 & & \\
\hline & Total & 82,908 & 12 & & & \\
\hline
\end{tabular}

Tabel 7. Nilai koefisien konstanta dan nilai uji t

\begin{tabular}{|c|c|c|c|c|c|c|}
\hline \multirow{2}{*}{\multicolumn{2}{|c|}{ Umur ternak }} & \multicolumn{2}{|c|}{$\begin{array}{c}\text { Unstandardized } \\
\text { Coefficients }\end{array}$} & $\begin{array}{c}\text { Standardized } \\
\text { Coefficients }\end{array}$ & \multirow[t]{2}{*}{$\mathrm{T}$} & \multirow[t]{2}{*}{ Sig. } \\
\hline & & $\mathrm{B}$ & Std. Error & Beta & & \\
\hline \multirow[b]{2}{*}{1} & (Constant) & $-1,785$ & 5,492 & & 325 &, 754 \\
\hline & $\begin{array}{l}\text { Lingkar } \\
\text { Dada }\end{array}$ & ,296 &, 115 & 674 & 2,581 & ,033 \\
\hline a. & \multicolumn{6}{|c|}{ Dependent Variable: Bobot badan } \\
\hline \multirow{2}{*}{\multicolumn{2}{|c|}{ Umur ternak }} & \multicolumn{2}{|c|}{$\begin{array}{l}\text { Unstandardized } \\
\text { Coefficients }\end{array}$} & $\begin{array}{l}\text { Standardized } \\
\text { Coefficients }\end{array}$ & $\mathrm{T}$ & Sig. \\
\hline & & B & Std. Error & Beta & & \\
\hline \multirow[b]{2}{*}{2} & (Constant) &, 760 & 9,213 & & ,082 & ,936 \\
\hline & $\begin{array}{l}\text { Lingkar } \\
\text { Dada }\end{array}$ &, 313 & 149 &, 535 & 2,101 & 059 \\
\hline
\end{tabular}

Berdasarkan data pada Tabel 7 diperoleh nilai t lingkar dada umur 1 tahun dan 2 tahun adalah sangat signifikan $(\mathrm{P}<0,33)$. Persamaan regresi ternak 1 tahun yaitu $: Y=-1,785+0,412$ yang dapat diartikan sebagai berikut konstanta sebesar $-1,785$ artinya bila bobot (x) nilainya adalah 0 , maka lingkar dada (LD) nialinya sebesar negatif $-1,785$. Sedangkan koefisien regresi variabel $(\mathrm{x})=$ 0,412 artinya jika bobot badan mengalami kenaikan $0,1 \mathrm{~kg}$ maka lingkar dada mengalami kenaikan $0,412 \mathrm{~cm}$. Sebaliknya pada ternak umur 2 tahun nilai lingkar dada adalah $(\mathrm{P}<0,59)$ persamaan regresi umur ternak 2 tahun memiliki persamaan $Y=0,760+0,313$ dapat diartikan sebagai konstantansebasar 0,760 . Artinya bila bobot badan (x) nilainya adalah 0 , maka lingkar dada sebesar negatif 0,760 . Koefisien regresi variable $(x)=0,313$ artinya jika bobot badan mengalami kenaikan $0,1 \mathrm{~kg}$ maka lingkar dada mengalami kenaikan $0,313 \mathrm{~cm}$.

\subsection{Pendugaan Bobot Badan Berdasarkan Tinggi Pundak}

Hubungan berbagai ukuran linear tubuh (Tinggi Pundak) berkorelasi sangat nyata $(\mathrm{P}<0,01)$ dengan bobot badan, untuk jelasnya dapat dilihat pada Tabel 8 .

Tabel 8. Hasil Analisis Regresi sederhana Pendugaan bobot badan kambing betina berdasarkan Tinggi pundak

\begin{tabular}{|c|c|c|c|c|}
\hline $\begin{array}{l}\text { Umur } \\
\text { ternak } \\
\end{array}$ & $\mathrm{R}$ & $\begin{array}{c}\mathrm{R} \\
\text { Square } \\
\end{array}$ & $\begin{array}{c}\text { Adjusted R } \\
\text { Square }\end{array}$ & Std. Error of the Estimate \\
\hline 1 &, $276^{\mathrm{a}}$ &, 076 &, 040 & 4,24090 \\
\hline \multicolumn{5}{|c|}{$\begin{array}{l}\text { a. Predictors: (Constant), Tinggi pundak } \\
\text { b.Dependent Variable: bobot badan }\end{array}$} \\
\hline $\begin{array}{l}\text { Umur } \\
\text { ternak } \\
\end{array}$ & $\mathrm{R}$ & $\begin{array}{c}\mathrm{R} \\
\text { Square } \\
\end{array}$ & $\begin{array}{c}\text { Adjusted R } \\
\text { Square }\end{array}$ & Std. Error of the Estimate \\
\hline 2 &, $660^{a}$ & , 436 &, 385 & 2,06176 \\
\hline
\end{tabular}

Hasil analisis regresi linear sederhana berdasarkan data pada Tabel 8 menunjukkan bahwa nilai koefisien korelasi (r) sebesar 0,276. Hal ini menunjukkan ada hubungan yang sangat kuat antara linear tubuh Tinggi pundak (TP) dengan bobot badan (BB). Koefisien determinasi $\left(\mathrm{R}^{2}\right)$ sebesar 0,076 . Memberi pengertian bahwa besarnya bobot badan ternak kambing betina dapat diterangkan oleh tinggi pundak adalah sebesar $07,6 \%$. Artinya tinggi pundak terhadap bobot badan hanya sebesar 07,6\%. Faktor lain yang berpengaruh terhadap bobot badan ternak kambing disebabkan oleh ketersediaan pakan, manajemen pemeliharaannya maka pertumbuhan ternak kambing yang dilepas bebas mencari makanan sendiri bobot tubuh ternak sangat baik. Sebaliknya pada ternak umur 2 tahun nilai koefisien korelasi (r) sebesar 0,660 . Hal ini menunjukkan ada hubungan yang sangat kuat antara linear tubuh tinggi pundak (TP) dengan bobot badan (BB).

Koefisien determinasi $\left(\mathrm{R}^{2}\right)$ sebesar 0,436 memberi pengertian bahwa besarnya bobot badan ternak kambing betina dapat diterangkan oleh tinggi pundak adalah sebesar $0,436 \%$. Artinya tinggi pundak berpengaruh terhadap bobot badan sebesar $0,436 \%$. Faktor lain yang dipengaruhi bobot badan ketersediaan pakan pada musim kemarau maka pertumbuhan, pemeliharaan ternak umur kedewasaan semakin menurun karena, kurangnya pakan yang memiliki nilai gizi tinggi menyebabkan tinggi pundak lambat. Hasil penelitian Permatasari et al., (2013) menunjukkan bahwa pada kambing kacang jantan, penggunaan ukuran tubuh (panjang muka, panjang telinga, lingkar dada, lebar dada, panjang badan, tinggi pundak, tinggi pinggul, lebar pinggul, panjang kaki depan, dan panjang kaki belakang) secara bersama-sama paling tepat untuk menentukan bobot badan dengan kontribusi sebesar 0,814. Hasil analisis variansi untuk mengetahui pengaruh linear tinggi pundak terhadap bobot badan seperti tersaji pada Tabel 9

Nilai F hitung 0,657 memberikan pengertian bahwa dengan persamaan $\mathrm{Y}=\mathrm{a}+\mathrm{bX}$ dimana komponen linear tubuh tinggi pundak berpengaruh sangat nyata terhadap bobot badan. Sebaliknya umur ternak 2 tahun nilai $F$ hitung
8,504 dengan persamaan $\mathrm{Y}=\mathrm{a}+\mathrm{bX}$ dimana komponen tinggi pundak berpengaruh sangat nyata terhadap bobot badan. Untuk mengetahui persamaan garis regresi dan nilai t dari variable tinggi pundak dapat dilihat padaTabel 10.

Tabel 9. Koefisien determinasi dan uji $\mathrm{t}$

\begin{tabular}{|c|c|c|c|c|c|c|}
\hline \multicolumn{2}{|c|}{ Umur ternak } & $\begin{array}{l}\text { Sum of } \\
\text { Squares }\end{array}$ & Df & $\begin{array}{c}\text { Mean } \\
\text { Square }\end{array}$ & $\mathrm{F}$ & Sig. \\
\hline \multirow{3}{*}{1} & Regression & 11,822 & 1 & 11,822 & ,657 &, $441^{\mathrm{b}}$ \\
\hline & Residual & 143,882 & 8 & 17,985 & & \\
\hline & Total & 155,704 & 9 & & & \\
\hline \multicolumn{7}{|c|}{$\begin{array}{l}\text { a. Dependent Variable: bobot badan } \\
\text { b. Predictors: (Constant), Tinggi pundak }\end{array}$} \\
\hline \multicolumn{2}{|c|}{ Umur ternak } & $\begin{array}{l}\text { Sum of } \\
\text { Squares }\end{array}$ & Df & $\begin{array}{l}\text { Mean } \\
\text { Square }\end{array}$ & $\mathrm{F}$ & Sig. \\
\hline \multirow{3}{*}{2} & Regression & 36,148 & 1 & 36,148 & 8,504 &, $014^{\mathrm{b}}$ \\
\hline & Residual & 46,759 & 11 & 4,251 & & \\
\hline & Total & 82,908 & 12 & & & \\
\hline
\end{tabular}

Tabel 10. Nilai koefisien konstanta dan nilai uji t

\begin{tabular}{|c|c|c|c|c|c|}
\hline \multirow[t]{2}{*}{ Umur ternak } & \multicolumn{2}{|c|}{$\begin{array}{c}\text { Unstandardized } \\
\text { Coefficients }\end{array}$} & \multirow{2}{*}{$\begin{array}{c}\text { Standardized } \\
\text { Coefficients } \\
\text { Beta }\end{array}$} & \multirow[t]{2}{*}{$\mathrm{T}$} & \multirow[t]{2}{*}{ Sig. } \\
\hline & $\mathrm{B}$ & Std. Error & & & \\
\hline (Constant) & 6,404 & 7,201 & & 889 & ,400 \\
\hline $\begin{array}{rr}1 & \text { Tinggi } \\
& \text { Pundak } \\
\end{array}$ & ,129 & 159 & 276 & 811 & ,441 \\
\hline
\end{tabular}

\begin{tabular}{|c|c|c|c|c|c|}
\hline \multicolumn{6}{|c|}{ a. Dependent Variable : Bobot badan } \\
\hline \multirow{2}{*}{ Umur ternak } & \multicolumn{2}{|c|}{$\begin{array}{c}\text { Unstandardized } \\
\text { Coefficients }\end{array}$} & $\begin{array}{l}\text { Standardized } \\
\text { Coefficients }\end{array}$ & \multirow{2}{*}{$\mathrm{T}$} & \multirow{2}{*}{ Sig. } \\
\hline & B & Std. Error & Beta & & \\
\hline (Constant) & $-4,875$ & 8,573 & &,- 569 & ,581 \\
\hline $\begin{array}{ll}2 & \text { Tinggi } \\
\text { Pundak }\end{array}$ & 459 & ,157 & 660 & 2,916 & ,014 \\
\hline
\end{tabular}

\section{a. Dependent Variable : Bobot badan}

Persamaan regresi ternak 1 tahun yaitu $\mathrm{Y}=6,404+0,129$, dapat diartikan sebagai berikut konstantan sebesar 6,404 artinya bila bobot (x) nilainya adalah 0 , maka tinggi pundak nilainya sebesar negatif 6,404. Koefisien regresi variabel $(\mathrm{x})=0,129$ artinya jika bobot badan mengalami kenaikan 0,1 $\mathrm{kg}$ maka tinggi pundak mengalami kenaikan $0,129 \mathrm{~cm}$. Sebaliknya, persamaan regresi umur ternak 2 tahun yaitu: $\mathrm{Y}=-4,873+0,459$. Artinya bila bobot badan (x) nilainya adalah 0 , maka tinggi pundak nilainya sebesar negatif $-4,873$. sebaliknya koefisien regresi variabel $(\mathrm{x})=0,459$ artinya jika bobot badan mengalami kenaikan $0,1 \mathrm{~kg}$ maka tinggi pundak mengalami kenaikan 0,459 $\mathrm{cm}$. Hal ini tidak jauh berbeda dengan penelitian Gunawan et al .(2008) bahwa koefisien regresi yang berpengaruh kuat dalam pendugaan bobot badan domba Garut adalah lingkar dada, tinggi pundak dan dalam dada. Basbeth et al.(2015) menyatakan bahwa perbedaan ukuran linear tubuh dipengaruhi pada ukuran lingkar, ketebalan dan berat tubuh.

\section{Simpulan}

Disimpulkan bahwa panjang badan pada umur ternak satu tahun dan lingkar dada memiliki pendugaan yang kuat dan dengan bobot badan dengan nilai masing-masing adalah 0,895 dan umur dua tahun 0,538 ,dan lingkar dada umur satu tahun 0,674 dan umur dua tahun lingkar dada 0,535. 2.Tinggi pundak memiliki keeratan hubungan yang kuat dan signifikasi dengan bobot badan ternak kambing.

\section{Pustaka}

Akdon, dan Riduwan. 2013. Rumus dan Data dalam Aplikasi Statistika, Bandung: Alfabeta

Bambang S.Y. 2005. Sapi Potong. Penebar Swadaya. Jakarta

Basbeth, A. H., W. S. Dilaga dan A.Purnomoadi. 2015. Hubungan antara ukuran-ukuran tubuh terhadap bobot badan kambing Jawarandu jantan umur muda di Kabupaten Kendal Jawa Tengah. AnimalAgricultureJournal, 4 (1) : 35-40.

Gunawan, A., K. Jamal, dan C. Sumantri. 2008. Pendugaan bobot badan melalui analisis morfometrik dengan pendekatan regresi terbaik pada domba Garut tipe pedaging, tangkas dan persilangannya. Majalah Ilmiah Peternakan, 11 (1) : 1-6.

Komariah., D. J. Setyono, dan Aslimah. 2015. Karakteristik Kuantitatif Dan Kualitatif Kambing dan Domba Sebagai Hewan Qurban Di Mitra Tani Farm. Buletin Peternakan, 39 (2):84-91.

Meivilia M. 2011. Pendugaan Bobot Hidup Pada Kambing Kacang Berdasarkan Ukuran Linier Tubuh. SKRIPSI. Departemen Ilmu Produksi Dan Teknologi Peternakan Fakultas Peternakan Institut Pertanian Bogor, Bogor.

Ni'am, H.U.M., A. Purmomoadi, dan S. Dartosukarno. 2012. Hubungan antara ukuran-ukuran tubuh dengan bobot badan sapi bali betina pada berbagi kelompok umur. AnimalAgriculture Journal,1 (1) : 541-556.

Parakassi, A. 1999. Ilmu Makanan dan Ternak Ruminansia. UI Press, Jakarta. 
Permatasari, T., E. Kurnianto dan E.Purbowati. 2013. Hubungan antaraukuranukuran tubuh dengan bobot badan pada kambing Kacang di Kabupaten Grobogan, Jawa Tengah. Animal Agriculture Journal, 2 (1): 28-34.

Pratama, A. A., E. Purbowati dan C. M. S. Lestari. 2016. Hubungan antara Ukuran-ukuran tubuh terhadap badan Domba Wonosobo Jantan di Kabupaten Wonosobo Jawa Tengah. Agromedia, 34 (2) : 11-15. 